\title{
The Significance of Erythrocyte Antigen Site Density
}

\author{
II. HEMOLYSIS
}

\author{
Leon W. Hoyer and Norma C. Trabold \\ From the Department of Medical and Pediatric Specialties, University of \\ Connecticut School of Medicine, Hartford, Connecticut 06105, and the \\ Department of Medicine, University of Rochester School of Medicine and \\ Dentistry, Rochester, New York 14620
}

A B S TRACT The importance of antigen site density has been studied by means of a model passive hemolysis system using red cells coupled with sulfanilic acid groups. Relative site numbers were estimated from the covalent linkage of sulfanilic acid- ${ }^{35} \mathrm{~S}$ to red cell membrane protein, and the effective antigen site number was determined with ${ }^{125}$ I-labeled rabbit IgG anti-sulfanilic acid (anti-S).

Immune hemolysis was demonstrated for red cells which had greater than a threshold number of antigen sites, the value of which was different for normal human cells $(80,000$ sites/cell), cells from a patient with paroxysmal nocturnal hemoglobinuria ( $\mathrm{PNH}) \quad(40,000$ sites/cell), and sheep red blood cells (RBC) (15,000 sites/ cell). Cells with antigen site densities below these values did not hemolyze when tested with $1 \mathrm{mg} / \mathrm{ml}$ purified rabbit IgM anti-S. 2-8 times greater antigen site densities were required to obtain hemolysis with IgG anti-S. Above the threshold value, hemolysis titers were proportional to the antigen site number until maximal values were obtained. The greater hemolytic efficiency of $\operatorname{IgM}$ antibody was demonstrated in this system, and it was established that the magnitude of the difference was related to the test cell antigen site density.

These data, taken with previously reported hemagglutination studies, have been used to develop a general classification of immune hemolysis and hemagglutination based on antigen site density and antibody class. It is suggested that the heterogeneity of blood group systems is caused by differences in the site separation of erythrocyte membrane antigens.

Presented, in part, at the Annual Meeting of the American Society of Hematology, Cleveland, Ohio, 8 December 1969 (1969. Blood. 34: 830. [Abstr.]) and the XIII International Congress of Hematology, Munich, 4 August 1970.

Received for publication 20 January 1971 and in revised form 17 February 1971.

\section{INTRODUCTION}

Blood group antibodies demonstrate heterogeneous in vivo and in vitro hemolytic properties $(1,2)$. As a general rule, IgM antibodies have greater hemolytic activity than IgG antibodies of the same specificity. Some IgM antibodies do not fix complement, however, and potent IgG hemolysins are recognized. The different properties of blood group antibodies seem to be related to the nature and distribution of antigen sites with which they react. As erythrocyte antigen site density markedly influences hemagglutination (3), we have similarly tested the relationship of antigen site density to immune hemolysis. A model system has been used in which red blood cells $(R B C)^{1}$ coupled with sulfanilic acid groups are tested with purified rabbit anti-sulfanilic (anti-S) antibodies. The hemolytic properties of sheep red cells, normal human cells, and cells from a patient with paroxysmal nocturnal hemoglobinuria $(\mathrm{PNH})$ have been determined in this passive hemolysis system.

\section{METHODS}

Antisera. The immunizing antigen was prepared by coupling diazotized sulfanilic acid to edestin by methods previously described (4). Young adult New Zealand albino rabbits were immunized by intravenous injection of $5 \mathrm{mg}$ of sulfanilic acid-azo-edestin three times a week for two courses of 4 wk separated by a 7 wk period. The animals were bled on the 5 th and 6 th days after the last injection, and anti-S sera were stored at $-20^{\circ} \mathrm{C}$ until used.

Rabbit anti-human RBC serum was prepared by repeated injections of washed human type $O \mathrm{RBC}$ (5). The rabbit anti-Forssman serum was obtained from the Monroe County, N. Y., Health Department Laboratories.

Preparation of purified antibody. Serum dialyzed against borate-saline buffer, $\mathrm{pH} 7.85$, was applied to columns of a

${ }^{1}$ Abbreviations used in this paper: anti-S, anti-sulfanilic acid; $\mathrm{PNH}$, paroxysmal nocturnal hemoglobinuria; RBC, red blood cells; VBS, veronal-buffered saline. 
sulfanilic acid-cellulose immunoadsorbent $(4,6)$. The antibody was eluted with the specific hapten ( $0.1 \mathrm{M}$ sulfanilic

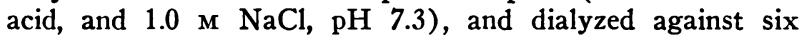
changes of borate-saline. Antibody recovery in the eluate was $45-73 \%$ of that in the serum applied to the column. IgG and IgM antibodies were separated by gel filtration through Sephadex G-200 after the eluate was concentrated by ultrafiltration. The purified IgM and IgG antibodies demonstrate single lines on immunoelectrophoresis when tested with a potent sheep anti-whole rabbit serum (3). Precipitating antibody was measured by a quantitative micro method (7) using sulfanilic acid-bovine serum albumin, and over $70 \%$ of the protein in the purified preparations was precipitable.

Preparation of sulfanilic acid-azo-erythrocytes. Blood collected from normal donors, and a patient with $\mathrm{PNH}$ was anticoagulated with acid-citrate-dextrose (ACD) (vacutainers containing solution B; Becton-Dickinson \& Co., Rutherford, N. J.). The preparation of ${ }^{85}$ S-diazotized sulfanilic acid has been described (3), and a single stock was used for all of the experiments reported.

Freshly thawed diazotized sulfanilic acid was diluted with cold phosphate-saline to the desired concentration and added dropwise to 5 volumes of thrice washed $10-20 \%(\mathrm{v} / \mathrm{v})$ erythrocytes in cold $\left(4^{\circ} \mathrm{C}\right)$ phosphate-saline. The cells were slowly stirred during the $10 \mathrm{~min}$ coupling period and were then washed twice with 40 volumes of phosphate-saline and once with veronal-buffered saline (VBS). The cells were used within $6 \mathrm{hr}$ of preparation.

${ }^{35} S$ measurement. Ghosts were prepared from the coupled cells by hypotonic lysis (8). The ghosts were digested with NCS (Amersham/Searle Corp., Arlington Heights, I1l.) ( $2 \mathrm{ml} / \mathrm{mg}$ membrane protein) and counted in toluene to which had been added $6 \mathrm{~g} /$ liter of 2,5-diphenyloxazole (PPO). Samples were counted using a Nuclear-Chicago automatic liquid scintillation detector, and at least 10,000 counts were accumulated. Quenching was determined by channels ratio and was less than $2 \%$.

Measurement of ${ }^{125}$ I-labeled antibody binding. Purified IgG anti-S and IgG fractions of anti-S sera (6) were labeled with ${ }^{125} \mathrm{I}$ (Cambridge Nuclear Corp., Cambridge, Mass.) by the iodine monochloride method (9). Over $98 \%$ of the radioactivity was precipitable by $10 \%$ trichloroaceticacid (TCA), and the labeled proteins had 1.5-2.0 iodine atoms/molecule with $\mathrm{SA}$ of $90-180 \mu \mathrm{Ci} / \mathrm{mg}$. Unlabeled IgG anti-S was added to these preparations to bring the protein content to $2.50 \mathrm{mg} / \mathrm{ml}$, and this mixture was absorbed twice with $\frac{1}{2}$ volume washed RBC.

Red cells coupled with sulfanilic acid were trace-labeled with ${ }^{51} \mathrm{Cr}$ (E. R. Squibb \& Sons, New York) to monitor cell recovery in the binding experiments (3). The cells were suspended in VBS to which had been added $2 \%(\mathrm{v} / \mathrm{v})$ heat-inactivated normal human $\mathrm{AB}$ serum, and the concentration adjusted to $10^{8} \mathrm{RBC} / \mathrm{ml}$ using a Coulter counter (Coulter Electronics Inc., Hialeah, Fla.). $0.5 \mathrm{ml}$ of the cell suspension and $0.5 \mathrm{ml}$ of ${ }^{125} \mathrm{I}$-labeled antibody (0.1 to $2.5 \mathrm{mg}$ antibody protein $/ \mathrm{ml}$ ) in VBS were added to a 12 $\times 75 \mathrm{~mm}$ uncoated polystyrene tube and placed on a bench rotator at $10 \mathrm{rpm}$ for $1 \mathrm{hr}$ at room temperature $\left(22-25^{\circ} \mathrm{C}\right)$. The tubes were then centrifuged $(850 \mathrm{~g}$ for $5 \mathrm{~min}$ ) and the cells transferred to a new tube using $2 \mathrm{ml}$ of VBS-1\% AB serum. After a second wash with $2 \mathrm{ml}$ VBS-1\% serum, the cells were lysed with $1 \mathrm{ml}$ of distilled water and the tubes counted using a two-channel Nuclear-Chicago crystal scintillation detector. Losses due to hemolysis and handling were less than $5 \%$ for the lightly coupled cells and $10-30 \%$

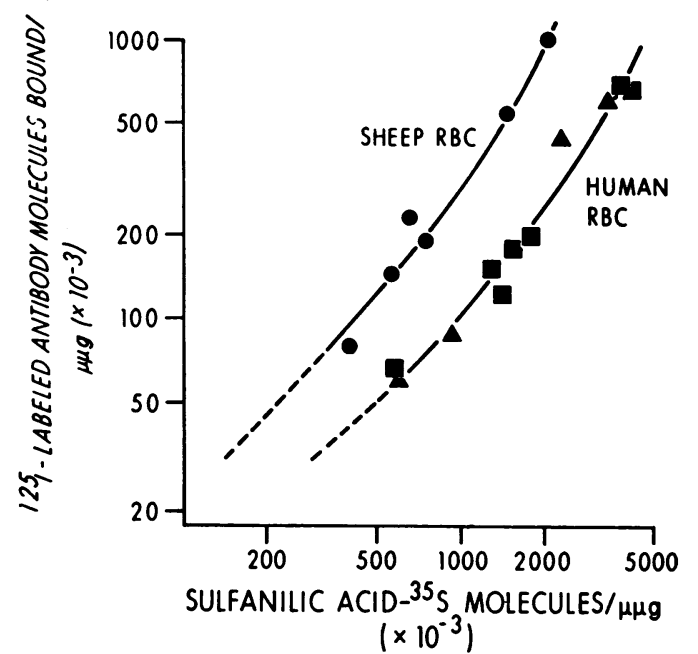

Figure 1 The relationship of the number of sulfanilic acid- ${ }^{85} \mathrm{~S}$ molecules and ${ }^{125} \mathrm{I}$-labeled antibody binding. Each point represents the extrapolated estimate of maximal antibody binding for a separate $\mathrm{RBC}$ preparation. Data are expressed in molecules/micromicrogram of membrane protein for coupled RBC. The membrane protein content of the cells is given in Table II. The values indicated by squares are for normal human $\mathrm{RBC}$, and the triangles indicate RBC from a patient with PNH. Data for coupled sheep cells are indicated for circles.

for the maximally coupled cells. The number of ${ }^{125} \mathrm{I}$-labeled antibody molecules/cell was calculated using a mol wt of 140,000 for rabbit IgG (10) and assuming that each IgG molecule was attached to a single $\mathrm{RBC}$ site.

The relationship of maximal extrapolated antibody binding-effective antigen site number-to the number of hapten groups coupled to normal human $\mathrm{RBC}$ has been reported as have estimates of the specificity and sensitivity of the method (3). Similar binding studies were done to measure the ratio of effective antigen sites to total hapten incorporation for sheep RBC and cells from a patient with $\mathrm{PNH}$. The data are given in Fig. 1 , which includes the previously established values for normal human RBC. It is apparent that red cells from the patients with $\mathrm{PNH}$ are like normal human red cells in this regard and that $10-18 \%$ of the bound hapten molecules are effective sites. However, as many as $50 \%$ of the sulfanilic acid groups coupled to sheep $\mathrm{RBC}$ were effective antigen sites. This correlation curve (Fig. 1) was used for all subsequent experiments to convert the primary data-sulfanilic acid- ${ }^{85} \mathrm{~S}$ molecules-to antigen sites.

Agglutination titers. $0.1 \mathrm{ml}$ of a dilution of anti-S serum or purified anti-S was added to $0.1 \mathrm{ml}$ of a $2 \frac{1}{2} \%$ suspension of coupled RBC in VBS-1\% normal human serum. After incubation for $1 \mathrm{hr}$ at room temperature, the $10 \times 60 \mathrm{~mm}$ glass tubes were centrifuged (200 $\mathrm{g}$ for $1 \mathrm{~min}$ ), and the agglutination pattern was read macroscopically. The degree of agglutination was graded from + to $4+$, and the end point was recorded as the reciprocal of the highest dilution giving a + pattern. Tubes in which there was no agglutination were tested for RBC sensitization after the cells were washed three times in $2 \mathrm{ml}$ of $0.9 \% \mathrm{NaCl} .0 .1 \mathrm{ml}$ of an optimal dilution of sheep anti-whole rabbit serum was added to the washed cells suspended in $0.1 \mathrm{ml}$ of $0.9 \% \mathrm{NaCl}$. 
TABLE I

Hemolysis of Coupled Normal Human RBC by Rabbit AntiHuman RBC and by Rabbit Anti-Sulfanilic Acid

\begin{tabular}{|c|c|c|c|c|c|}
\hline \multirow{2}{*}{$\begin{array}{l}\text { Antigen } \\
\text { sites/ } \\
\text { cell }\end{array}$} & \multicolumn{3}{|c|}{ Hso anti-human RBC } & \multicolumn{2}{|c|}{$\begin{array}{c}\mathrm{H}_{80} \text { anti-sulfanilic } \\
\text { acid* }^{*}\end{array}$} \\
\hline & $\begin{array}{l}\text { Uncoupled } \ddagger \\
\text { (a) }\end{array}$ & $\begin{array}{l}\text { Coupled } \\
\text { (b) }\end{array}$ & $\begin{array}{l}\text { Ratio } \\
\text { (a)/(b) }\end{array}$ & $\begin{array}{l}\text { Mea- } \\
\text { sured }\end{array}$ & $\begin{array}{l}\text { Cor- } \\
\text { rected }\end{array}$ \\
\hline & \multicolumn{3}{|c|}{$U_{n i t s / m l}$} & \multicolumn{2}{|c|}{$U n i t s / m l$} \\
\hline 43,000 & 103 & 123 & 0.84 & 3 & 3 \\
\hline 73,000 & 106 & 125 & 0.85 & 3 & 3 \\
\hline 78,000 & 103 & 136 & 0.76 & 12 & 9 \\
\hline 108,000 & 115 & 135 & 0.84 & 11 & 9 \\
\hline 225,000 & 135 & 170 & 0.79 & 47 & 37 \\
\hline 300,000 & 106 & 170 & 0.62 & 63 & 39 \\
\hline 345,000 & 106 & 220 & 0.48 & 90 & 43 \\
\hline 360,000 & 114 & 204 & 0.56 & 115 & 64 \\
\hline 570,000 & 115 & 250 & 0.46 & 185 & 85 \\
\hline 640,000 & 114 & 225 & 0.51 & 230 & 117 \\
\hline
\end{tabular}

* Titers given for coupled RBC only. There was no detectable lysis of uncoupled RBC by the anti-sulfanilic acid.

$\ddagger$ Control uncoupled cells tested in parallel with erythrocytes to which had been coupled varied numbers of sulfanilic acid groups.

$\S$ The measured $\mathrm{H}_{50}$ anti-S multiplied by the ratio uncoupled/ coupled $\mathrm{H}_{50}$ anti-human $\mathrm{RBC}$ to correct for "nonspecific" increase in hemolysis.

The agglutination pattern was read after immediate centrifugation ( $200 \mathrm{~g}$ for $1 \mathrm{~min}$ ).

Hemolysis titers. $0.5 \mathrm{ml}$ of a dilution of antibody was incubated with $1.0 \mathrm{ml}$ of $1 \%$ suspension of red cells for $10 \mathrm{~min}$ at room temperature before adding $1 \mathrm{ml}$ of a dilution of guinea pig serum. After $30 \mathrm{~min}$ of incubation at $37^{\circ} \mathrm{C}$, the unlysed cells were removed by centrifugation, and the optical density of the supernatant was measured at $540 \mathrm{~m} \mu$. Disposable $12 \times 75$ glass tubes were used, and all dilutions were made with VBS. The complement source, reconstituted lyophilized guinea pig serum (Behring Diagnostics, Woodbury, N. Y.), was absorbed with normal human or sheep RBC before use. Excess complement was used in these studies, and it was established that $1: 25$ dilution of absorbed guinea pig serum supported maximal hemolysis of sheep cells and that a 1:10 dilution supported maximal hemolysis of human cells. The $\mathrm{H}_{s 0}$ was determined by graphic interpretation of a von Krogh plot (11). The rabbit IgM anti-S had the same dose-response slope in this plot as did rabbit IgM anti-Forssman antibody. Similarly, the slope for IgG anti-S, though greater than that for the IgM anti-S, was the same as that of rabbit IgG anti-human $\mathrm{RBC}$ and that of human IgG anti-A (5).

Protein measurement. The Lowry, Rosebrough, Farr, and Randall phenol method (12) was used with human Cohn Fraction II (Pentex Biochemical, Kankakee, Ill.) as standard for measurement of immunoglobulin preparations and with ovalbumin (Nutritional Biochemicals Corporation, Cleveland, Ohio) as reference standard for determinations of RBC membrane protein.

Buffer solutions. The composition of the $10 \%$ boratesaline, $\mathrm{pH} 7.85$ (4), the VBS (13, alternative procedure), the hypotonic phosphate-saline EDTA (8), and the isotonic phosphate-saline (3) buffers have been previously described. Calcium and magnesium were omitted from the VBS for all studies other than immune hemolysis.

\section{RESULTS}

Covalent coupling of the sulfanilic acid groups to red cells has been shown to have minimal effect on the membrane properties $(3,14)$. In a contrast with the unchanged agglutination properties of coupled red cells (3), a consistent dose-related increase in hemolysis was recognized (Table I). This "nonspecific" increase in hemolysis was determined in each experiment so that the specific anti-S hemolysis could be calculated. Anti-S titers for coupled human $R B C$ were multiplied by the ratio $\mathrm{H}_{80}$ anti-human $\mathrm{RBC}$ (uncoupled cells)/Hoo antihuman RBC (coupled cells). The values given in Table I include the highest sulfanilic acid concentrations used and, therefore, the greatest correction required for this effect. A similar small nonspecific increase in hemolysis of hapten-coupled sheep RBC was identified with a rabbit anti-Forssman serum, and the titers of coupled cells were corrected by the method indicated in Table I. The coupled cells were stable throughout these experiments, and there was no significant spontaneous hemolysis.

Hemolysis and hemagglutination were measured using three kinds of cells coupled with sulfanilic acid: normal human $\mathrm{RBC}, \mathrm{RBC}$ from a patient with $\mathrm{PNH}$, and sheep $\mathrm{RBC}$. The hemagglutination patterns were consistent for the three kinds of cells with threshold densities of 10,000-20,000 antigen sites/cell required for agglutination by a high titer rabbit antiserum and with maximal agglutination titers of $1: 1600$ for cells with greater than 200,000 antigen sites/cell. The agglutination properties of the PNH and sheep RBC were the same as those of normal human RBC which had the same number of antigen sites/cell (3).

The hemolytic properties of the three kinds of coupled $\mathrm{RBC}$ were very distinct, however, when cells with the

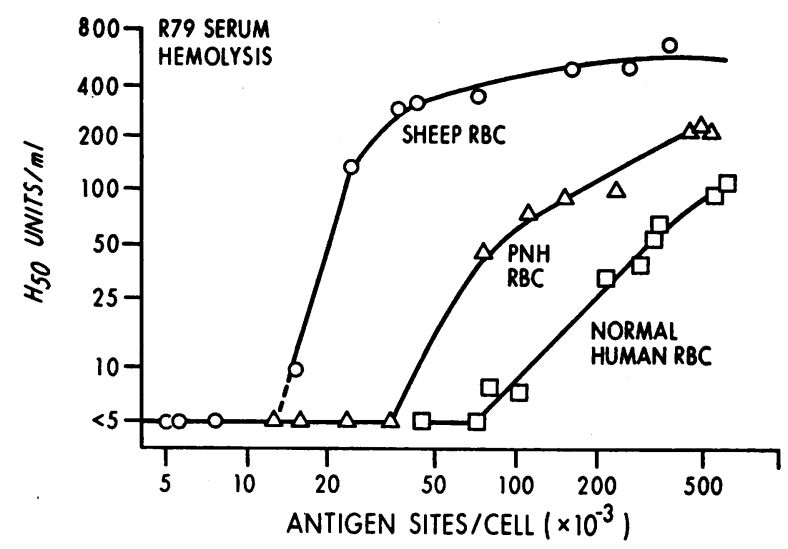

FIGURE 2 The relationship of hemolysis to antigen site number for different kinds of coupled RBC. A single rabbit antiserum was used for these experiments. 
TABLE II

Surface Area of $R B C$

\begin{tabular}{|c|c|c|c|c|c|}
\hline & \multirow[b]{2}{*}{$\begin{array}{c}\text { Mean } \\
\text { corpus- } \\
\text { cular } \\
\text { volume* }\end{array}$} & \multicolumn{2}{|c|}{ Membrane protein } & \multicolumn{2}{|c|}{ Surface area } \\
\hline & & $\begin{array}{l}\mu \mu \mathrm{g} / \\
\text { cell } /\end{array}$ & $\begin{array}{c}\text { As a } \\
\text { fraction } \\
\text { of normal } \\
\text { human } \\
\text { RBC }\end{array}$ & $\mu^{2}$ & $\begin{array}{c}\text { As a } \\
\text { fraction } \\
\text { of normal } \\
\text { human } \\
\text { RBC }\end{array}$ \\
\hline Normal & $\mu^{3}$ & & & & \\
\hline human & 94.3 & 0.607 & 1.00 & $163 \S$ & 1.00 \\
\hline $\mathrm{PNH}$ & 143.8 & 0.788 & 1.30 & $216 \|$ & 1.33 \\
\hline Sheep & 32.5 & 0.190 & 0.31 & $67 \S$ & 0.41 \\
\hline
\end{tabular}

* Mean of 10 measurements.

$\ddagger$ Nonhemoglobin membrane protein determined after hypotonic lysis of red cells (8).

\$ Ponder (15).

|| Estimated from the mean corpuscular volume for normal human and PNH RBC assuming that area is related to the square of the radius and volume to the cube of the radius.

same number of antigen sites were compared (Fig. 2). These data are consistent with the long recognized increased susceptibility to hemolysis of $\mathrm{PNH}$ and sheep $\mathrm{RBC}$. The disparity in these cells' surface areas overemphasizes differences, however. PNH cells and sheep cells may be more properly compared with normal human RBC with the same number of antigen sites $/ \mu^{2}$. The membrane protein content of ghosts provided an indirect measure of the relative surface areas of the three kinds of RBC (Table II). Surface area measurements reported by Ponder (15) and calculation of the relationship of surface area to volume indicate that membrane protein content provides a satisfactory estimate of relative surface area. The usefulness of this measurement is probably related to the standardized conditions for the osmotic hemolysis of the three kinds of red cells (8).

A comparison of cells with the same number of antigen sites/micromicrogram of membrane protein provides, therefore, a better indication of the effect of antigen site density (Fig. 3). PNH and sheep cells have similar properties when compared in this way although sheep cells have a slightly greater maximal titer. Normal human erythrocytes, coupled so that they have the same antigen site density, are clearly less susceptible to immune hemolysis.

Purified IgM and IgG antibodies were tested with these cells to determine the effect of antigen site density on their relative hemolytic efficiencies. The hemolytic titers of specifically purified IgG and IgM anti-S with coupled sheep, $\mathrm{PNH}$, and normal human $\mathrm{RBC}$ are given in Fig. 4. The 10- to 500 -fold greater specific activity of IgM antibody was noted over the entire range of antigen site densities for all three RBC types. These data also indicate that most of the increased sensitivity to hemolysis of sheep and PNH cells by unfractionated serum (Fig. 3) is due to IgM anti-S in that serum. IgG antibody was less effective in causing hemolysis, and the differences among sheep, $\mathrm{PNH}$, and normal human $\mathrm{RBC}$ of the same antigen site density were much less prominent than when IgM was tested. IgG hemolysis of $\mathrm{PNH}$ and normal human cells of the same antigen site density was different only at the threshold site densities. Coupled sheep RBC had the same threshold site density for IgG hemolysis as the human RBC, but increased hemolytic titers were obtained at high site densities.

These data, taken with the previously reported hemagglutination studies (3), allow a general classification of hemagglutination and hemolysis as related to antigen site density. Fig. 5 indicates the properties of normal human RBC coupled with sulfanilic acid and tested with IgM and IgG anti-S. It is apparent that cells can be prepared which have a wide range of immunohematologic properties and that these properties are related to antigen site density. Cells of very low site density are not hemolyzed by anti-S at any antibody concentration and are agglutinated in saline by IgM but not IgG. In contrast, heavily coated cells are agglutinated and lysed by both IgG and IgM anti-S. This immunohematologic spectrum includes the range of properties of blood group antibodies.

\section{DISCUSSION}

The quantitative relationship of erythrocyte antigen content and hemolysis has been studied using a model system in which diazotized sulfanilic acid ${ }^{35} \mathrm{~S}$ is coupled to RBC. The hapten-RBC linkage has been shown to be stable during repeated washes of the coupled cells and is intact in membrane protein extracted from $\mathrm{RBC}(3$,

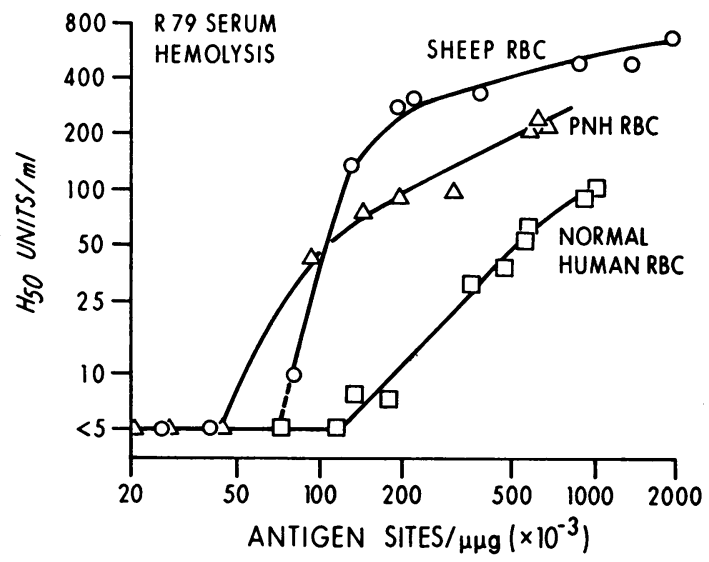

FIgURE 3 The relationship of hemolysis to antigen site density expressed as sites/micromicrogram of membrane protein. This comparison compensates for the marked differences in cell size (Table II). 


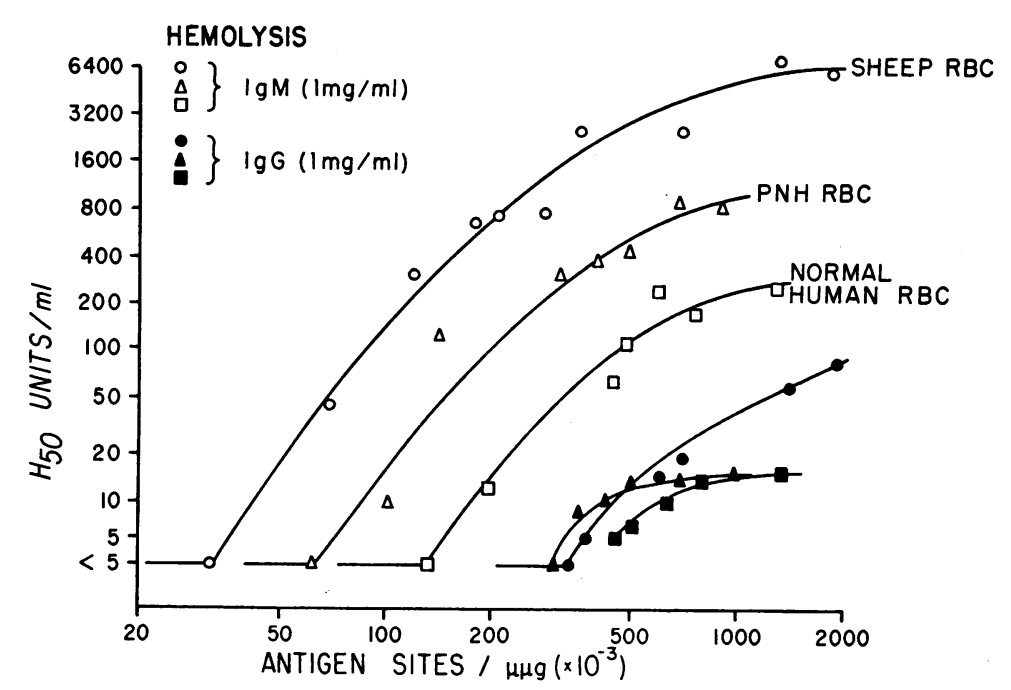

FIGURE 4 The relationship of antigen site density and hemolysis by purified IgM and IgG anti-S. The open figures indicate $\operatorname{IgM}(1 \mathrm{mg} / \mathrm{ml})$, and the closed figures indicate $\mathrm{IgG}(1 \mathrm{mg} / \mathrm{ml})$. The values indicated by circles are for sheep $\mathrm{RBC}$, the triangles indicate $\mathrm{RBC}$ from a patient with $\mathrm{PNH}$, and the squares indicate normal human $\mathrm{RBC}$.

14). Sulfanilic acid does not bind to nonmembrane proteins (primarily hemoglobin) under the conditions used in these experiments and coupling to plasma proteins adsorbed to the $\mathrm{RBC}$ was minimized by thorough washing of the RBC before adding the diazotized hapten.

The number of effective antigen sites/cell was directly related to the number of hapten groups coupled to the RBC membrane (Fig. 1). This value-the antigen site density-is an average value for the population of red cells and the amount of heterogeneity within this cell population is not known with certainty. Serologic and

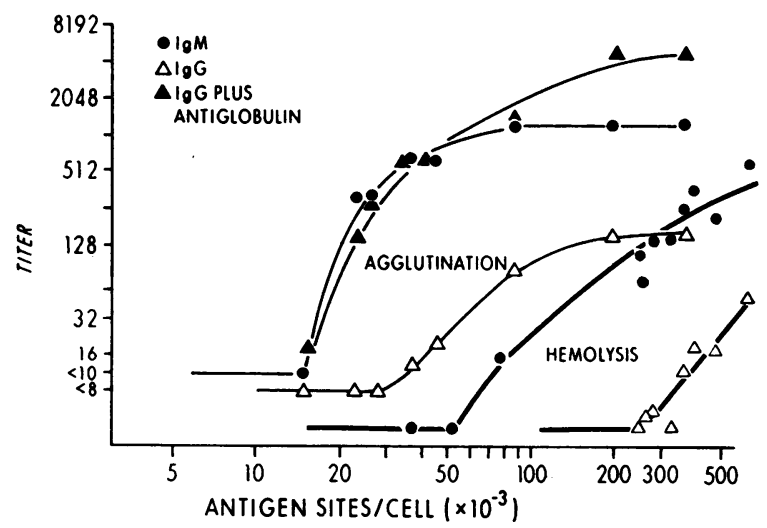

FIGURE 5 The relationship of hemolysis and hemagglutination to antigen site number for coupled normal human RBC tested with purified $\operatorname{IgM}(1 \mathrm{mg} / \mathrm{ml})$ and $\operatorname{IgG}(1 \mathrm{mg} / \mathrm{ml})$ anti-S. The hemagglutination titers are indicated by thin lines, and the $\mathrm{H}_{50}$ hemolytic titers are indicated by heavy lines. immunofluorescence data indicating uniform coupling were presented in a previous paper which described the properties of this model system (3). The linear von Krogh plots ( $\log y / 1-y$ vs. $\log$ antibody content) over the $10-90 \%$ hemolysis range also indicate that the population of coupled cells is homogeneous.

The consistency of the slope of these plots over the entire range of antigen site densities and the similarities of these slopes to those obtained with anti-Forssman and anti-A antibodies, are consistent with a uniform distribution of the $\mathrm{S}$ sites over the RBC membrane. Electron microscopy has established that the A antigen of human $\mathrm{RBC}$ and the Forssman antigen on sheep $\mathrm{RBC}$ have a uniform distribution $(16,17)$. Electron microscopic studies using ferritin-labeled antibodies will be required to establish the fine structural distribution of the $\mathrm{S}$ antigen sites.

The relative threshold site densities for hemolysis have been clearly established for this model system. Threshold site densities may be quite different for other red cell antigens, however, as may be the specific activities of purified antibodies. The physicochemical nature of the antigen, the fine structural antigen "distribution on the RBC membrane, and the antibody affinity (18) must all be considered in addition to antigen site density.

The difference in hemolytic susceptibility of red cells from different species has been widely recognized (19, 20). These studies with our model system allow the first direct comparison of cells which have the same antigen and similar antigen densities. Meaningful comparisons 
can best be made with this kind of quantitative passive hemolysis data. The increased susceptibility of sheep $\mathrm{RBC}$ to immune hemolysis has been verified using this model system.

The increased hemolytic susceptibility of $\mathrm{PNH}$ cells is also apparent in these studies. Rosse and Dacie demonstrated differences of a similar magnitude using anti-I, anti- $\mathrm{p}^{\mathbf{k}}$, a Donath-Landsteiner antibody, and Shigella passive hemolysis (21). They found that both the IgM and IgG antibodies had increased hemolytic activity when tested with $\mathrm{PNH}$ cells. More detailed studies of two Donath-Landsteiner (IgG) antibodies have been reported by Hinz, Picken, and Lepow (22). The hemolytic titer of both antibodies was 4-8 times higher when tested with $\mathrm{PNH}$ erythrocytes instead of normal cells. The discrepancy between the increased lysis of PNH cells by human IgG antibodies and the similar lysis of normal and PNH cells of the rabbit IgG anti-sulfanilic acid is the subject of continuing investigation.

Several recent studies have suggested a relationship of immune hemolysis to antigen site density (23-26). An effect of antigen coupling concentration and, by inference, antigen density on the hemolytic effectiveness of IgM anti-arsanilic acid has been reported by Linscott (23). The amount of antibody needed to fix $\mathrm{C} 1$ increased as the coupling concentration of hapten was reduced, and the conversion of bound $\mathrm{C} 1$ to sites of membrane damage was less efficient.

An analogous effect of hapten coupling concentration was noted by Pasanen and Makela using dinitrophenylcoated sheep RBC in their studies of hemolytic plaque formation by isolated lymphoid cells (24). The hapten concentration influenced both plaque number and size. Assays done with heavily coupled sheep RBC suggested that cells synthesizing IgG antibody could produce direct plaques, and they noted that it is an oversimplification to equate IgM production with direct plaques and anti-globulin enhancement (indirect plaques) with IgG synthesis. The data given in Fig. 4 indicate that direct hemolysis by IgG antibody is expected whenever the indicator erythrocytes have sufficiently great antigen site density.

The recognition that low antigen site density prevents complement-mediated hemolysis emphasizes the role of antigen content and distribution in the modulation of antibody functional properties. Rosse's studies of $\mathrm{C} \overline{1}$ fixation and transfer by $\mathrm{Rh}$ antibodies provided the first evidence that immunoglobulin class is not the only factor determining complement fixation by blood group antigens (25). Although individual $\mathrm{Rh}$ antibodies did not fix Cì when tested alone, even when present in high concentrations, they initiated $C \overline{1}$ fixation if present in combinations. As this allowed juxtaposition of two or more IgG molecules, $C \overline{1}$ could be fixed by this com- posite antigen. The properties of cells with few hapten groups are similar to those of blood groups systems which have a low antigen site density.

The variable cytolytic properties of anti-tumor antibodies may also be interpreted within the formulation (26). It is likely that antibodies which do not fix complement are bound by tumor antigens which are separated so that complement binding cannot be initiated. Complement-fixing antibodies are, in this view, those which react with more closely spaced cell surface antigens.

These and other recent studies $(27,28)$ indicate the importance of antigen site interaction in complement fixation. Our data permit a quantitative evaluation of this interaction if it is assumed that the antigen sites are uniformly distributed on the membrane surface. Cells which have the minimum site number needed for agglutination $(20,000$ sites/cell) have, with this assumption of uniform distribution, an average antigen site separation of $904 \mathrm{~A}$. The minimum site number for hemolysis $(80,000$ sites/cell) requires closer spacing, however, and the average site separation is then approximately $400 \mathrm{~A}$. This value is very close to the maximum dimension of an IgM pentamer (350-400 A) in electron micrographs (29). It may indicate the maximum site separation which still allows two $\operatorname{IgM}$ subunits to act together in $\mathrm{C1}$ fixation.

These studies suggest that heterogeneity in hemagglutination and hemolysis by blood group systems is a result of the different properties of IgG and IgM antibodies and of variation in antigen site density. They provide the first direct evidence that differences in antigen site density determine $\mathrm{RBC}$ immunohematologic properties. This model allows the many speculations about the differences between blood group systems to be tested against a simple experimentally established framework. The differences between $\mathrm{AB}$ and $\mathrm{Rh}$ antibodies are resolved by this formulation in light of the marked differences in antigen site numbers (30-33).

\section{ACKNOWLEDGMENTS}

We wish to thank Dr. W. E. Vannier for providing the sulfanilic acid-cellulose immunoadsorbent and some of the antisera. We have had many helpful discussions with Dr. John P. Leddy during the course of these studies.

The studies were supported by U. S. Public Health Service Grants He-13594 and HE-11841.

\section{REFERENCES}

1. Leddy, J. P. 1966. Immunological aspects of red cell injury in man. Seminars Hematol. $3: 48$.

2. Mollison, P. L. 1967. Blood Transfusion in Clinical Medicine. Blackwell Scientific Publications Ltd., Oxford. 4th edition.

3. Hoyer, L. W., and N. C. Trabold. 1970. The significance of erythrocyte antigen site density. I. Hemagglutination. J. Clin. Invest. 49: 87. 
4. Vannier, W. E., W. P. Bryan, and D. H. Campbell. 1965. The preparation and properties of a hapten-cellulose antibody adsorbent. Immunochemistry. 2: 1 .

5. Sears, D. A., R. I. Weed, and S. N. Swisher. 1964. Differences in the mechanism of in vitro immune hemolysis related to antibody specificity. J. Clin. Invest. 43: 975.

6. Hoyer, L. W., W. E. Vannier, and L. Renfer. 1968. Antibody elution from hapten-cellulose immunadsorbents : the effects of hapten structure, $\mathrm{pH}$ and salt concentration. Immunochemistry. 5: 277.

7. Mage, R., and S. Dray. 1965. Persistent altered phenotypic expression of allelic gamma-G-immunoglobulin allotypes in heterozygous rabbits exposed to isoantibodies in fetal and neonatal life. J. Immunol. 95: 525.

8. Rega, A. F., R. I. Weed, C. F. Reed, G. G. Berg, and A. Rothstein. 1967. Changes in the properties of human erythrocyte membrane protein after solubilization by butanol extraction. Biochim. Biophys. Acta. 147: 297.

9. Helmkamp, R. W., R. L. Goodland, W. F. Bale, I. L. Spar, and L. E. Mutschler. 1960. High specific activity iodination of $\gamma$-globulin with iodine-131 monochloride. Cancer Res. 20: 1495.

10. Small, P. A., Jr., and M. E. Lamm. 1966. Polypeptide chain structure of rabbit immunoglobulins. I. $\gamma \mathrm{G}$-immunoglobulin. Biochemistry. 5: 259.

11. Campbell, D. H., J. S. Garvey, N. E. Cremer, and D. H. Sussdorf. 1964. Methods in Immunology. W. A. Benjamin, Inc., New York. 172.

12. Lowry, O. H., N. J. Rosebrough, A. L. Farr, and R. J. Randall. 1951. Protein measurement with the Folin phenol reagent. J. Biol. Chem. 193: 265.

13. Kabat, E. A., and M. M. Mayer. 1961. Experimental Immunochemistry. Charles C. Thomas, Publisher, Springfield, Ill. 2nd edition. 149.

14. Berg, H. C. 1969. Sulfanilic acid diazonium salt: a label for the outside of the human erythrocyte membrane. Biochim. Biophys. Acta. 183: 65.

15. Ponder, E. 1948. Hemolysis and Related Phenomena. Grune \& Stratton, Inc., New York. 14.

16. Lee, R. E., and J. D. Feldman. 1964. Visualization of antigenic sites of human erythrocytes with ferritin-antibody conjugates. J. Cell Biol. 23: 396.

17. Haferkamp, O., H. Schafer, W. Wessel, and K. C. Hsu. 1969. Studies of the antigen-antibody reaction by electron microscopy. I. On the transfer of agglutinating antibodies from sensitized sheep erythrocytes to freshly added (unsensitized) red blood cells. Int. Arch. Allergy Appl. Immunol. 36: 298.

18. Fauci, A. S., M. M. Frank, and J. S. Johnson. 1970. The relationship between antibody affinity and the efficiency of complement fixation. J. Immunol. 105: 215.
19. Linscott, W. D. 1967. Immune hemolysis: an interspecies study. J. Immunol. 98: 991.

20. Neter, E., L. F. Bertram, D. A. Zak, M. R. Murdock, and C. E. Arbesman. 1952. Studies on hemagglutination and hemolysis by Escherichia coli antisera. J. Exp. Med. 96: 1 .

21. Rosse, W. F., and J. V. Dacie. 1966. Immune lysis of normal human and paroxysmal nocturnal hemoglobinuria (PNH) red blood cells. I. The sensitivity of $\mathrm{PNH}$ red cells to lysis by complement and specific antibody. $J$. Clin. Invest. $45: 736$

22. Hinz, C. F., Jr., M. E. Picken, and I. H. Lepow. 1961. Studies on immune hemolysis. I. The kinetics of the Donath-Landsteiner reaction and the requirement for complement in the reaction. J. Exp. Med. 113: 177.

23. Linscott, W. D. 1970. An antigen density effect on the hemolytic efficiency of complement. J. Immunol. 104: 1307.

24. Pasanen, V. J., and O. Mäkelä. 1969. Effect of the number of haptens coupled to each erythrocyte on haemolytic plaque formation. Immunology. 16: 399.

25. Rosse, W. F. 1968. Fixation of the first component of complement (C'la) by human antibodies. J. Clin. Invest. 47: 2430 .

26. Möller E., and G Möller. 1962. Quantitative studies on the sensitivity of normal and neoplastic mouse cells to the cytotoxic action of isoantibodies. J. Exp. Med. 115: 527.

27. Rosse, W. F., H. J. Rapp, and T. Borsos. 1967. Structural characteristics of hemolytic antibodies as determined by the effects of ionizing radiation. J. Immunol. 98: 1190 .

28. Cohen, S. 1968. The requirement for the association of two adjacent rabbit $\gamma \mathrm{G}$-antibody molecules in the fixation of complement by immune complexes. J. Immunol. 100 : 407.

29. Chesebro, B., B. Bloth, and S.-E. Svehag. 1968. The ultrastructure of normal and pathological IgM immunoglobins. J. Exp. Med. 127: 399.

30. Greenbury, C. L., D. H. Moore, and L. A. C. Nunn. 1963. Reaction of 7S and 19S components of immune rabbit antisera with human group $A$ and $A B$ red cells. Immunology. 6: 421 .

31. Economidou, J., N. C. Hughes-Jones, and B. Gardner. 1967. Quantitative measurements concerning $A$ and $B$ antigen sites. Vox Sang. 12: 321.

32. Masouredis, S. P. 1960. Relationship between RHo (D) genotype and quantity of $\mathrm{I}^{181}$ anti-RHo (D) bound to red cells. J. Clin. Invest. 39: 1450.

33. Hughes-Jones, N. C., B. Gardner, and R. Telford. 1963. Studies on the reaction between the blood-group antibody anti-D and erythrocytes. Biochem. J. 88: 435 . 